\title{
WINTER WHEAT LEAF DISEASES AND SEVERAL STEPS INCLUDED IN THEIR INTEGREATED CONTROL: A REVIEW
}

\author{
Agrita Švarta, Gunita Bimšteine \\ Latvia University of Life Sciences and Technologies, Latvia \\ agrita.svarta@1lu.lv
}

\begin{abstract}
Winter wheat (Triticum aestivum L.) leaf diseases is an important risk factor that influences the productivity and quality of wheat production. The aim of the present study was to review published scientific literature about the possibilities for integrated control of winter wheat leaf diseases. The most common and economically important wheat leaf diseases are Septoria leaf blotch (caused by Zymoseptoria tritici), tan spot (caused by Pyrenophora triticirepentis), yellow rust (caused by Puccinia striiformis), and powdery mildew (caused by Blumeria graminis). The severity of winter wheat diseases has varied significantly over the years and depended on meteorological conditions, variety resistance to pathogen, and tillage system. The crop rotation and an efficient residue management significantly decrease the development of tan spot. The development of Septoria leaf blotch mainly depends on meteorological conditions, but agronomic practice is less important. The use of disease-resistant varieties is the most economical, safe, and effective way to prevent and control wheat leaf diseases. Many European countries have a number of decision support systems for optimizing and minimizing the use of fungicides. Decision support systems are based on control thresholds and meteorological observations. Most used parameters are: air temperature, relative air humidity, and precipitation. These systems have been developed in the countries with a milder climate and a longer vegetation period than Latvia, and systems need to be adapted to Latvian conditions. The main groups of fungicides for disease control in winter wheat are azoles, strobilurin, and carboxamides. The results of many studies about the effectiveness of fungicide groups show that the obtained results differ and further research is needed.
\end{abstract}

Key words: Pyrenophora tritici-repentis, Zymoseptoria tritici, fungicides, decision-support systems.

\section{Introduction}

Wheat (Triticum aestivum L.) is one of the most profitable crops in Latvia, especially in the central part of Latvia. According to the data of Central Statistical Bureau of Latvia, in 2017 wheat areas reached 448.2 thous. ha and covered $38.8 \%$ of the total field crop area (CSB, 2019). Wheat leaf diseases are widespread throughout the world and are an important risk factor for obtaining high and stable grain yields. The most economically important wheat leaf diseases are Septoria leaf blotch (caused by Zymoseptoria tritici), tan spot (caused by Pyrenophora triticirepentis) (Ronis \& Semaškiene, 2011; Fernandez et al., 2016; Bankina et al., 2018), yellow rust (caused by Puccinia striiformis), and powdery mildew (caused by Blumeria graminis) (Jørgensen et al., 2014; Fernandez et al., 2016).

Integrated disease management is built on agronomic (for example, crop rotation, crop management), mechanical, physical and biological principles, resorting to selective pesticide use in situations that cannot be successfully managed with other tools (Barzmann et al., 2014). Reliable and timely information on plant fungal disease epidemics is crucial for optimizing the use of fungicides, therefore integrated disease management is based on monitoring and decision-support systems (Fones \& Gurr, 2015). A lot of investigations and surveys related to the development and control of wheat leaf diseases have been carried out and various decision support models have been developed in different countries, but results are not conclusive.
The aim of the present study was to summarize the latest results of researches and identify the possibilities for integrated control of winter wheat leaf diseases.

\section{Materials and Methods}

Monographic method was used in this study. Scientific literature from different journals and monographs was used in this review. The literature includes information about winter wheat leaf diseases: their biology, possibilities for integrated control, and decision support systems. The review includes information from investigations performed in different countries with different agroclimatic conditions.

\section{Results and Discussion}

Winter wheat leaf diseases

The results of a six-year (2012-2017) field experiment in Latvia showed that tan spot was the dominant disease. The level of Septoria leaf blotch was significantly lower and exceeded the severity of tan spot only in 2015. Powdery mildew was observed every year; however, the disease severity never reached 2\% during the evaluation (Bankina et al., 2018).

In Latvia, tan spot was first identified only in the first half of the 1990s, and studies show that the spread of the disease has rapidly increased with the increase in wheat percentage in a crop rotation and with the enlargement of the area under minimum tillage (Bankina et al., 2011). In Denmark, tan spot occurs periodically (Matzen et al., 2019). The time of the appearance of the first tan spot symptoms 
depends on meteorological conditions and varieties. On susceptible wheat leaves, the pathogen $P$. triticirepentis produces characteristic oval to diamondshaped lesions. On resistant and partially resistant wheat, lesion size is reduced and chlorosis and necrosis may be absent (De Wolf et al., 1998). In Lithuania, the first visible symptoms of tan spot were detected at the beginning of stem elongation growth stage (Ronis \& Semaškiene, 2011) but in Latvia, only after flowering (Bankina \& Priekule, 2011).

The fungus propagates asexually by conidia and sexually by ascospores (Cotuna et al., 2015), which are wind-born. Wheat straw debris, where pseudothecia with ascospores develop, is the main source of infection (De Wolf et al., 1998; Bankina \& Priekule, 2011; Ronis \& Semaškiene, 2011; Cotuna et al., 2015). In Latvia, pseudothecia develop on the stems about two months after harvesting, but differentiation of spores starts only in spring (March-April). Ripe ascospores are observed during May (Bankina \& Priekule, 2011). The optimal temperature for maturation of pseudothecia and ascospores ranges between +15 and $+18^{\circ} \mathrm{C}$ (Wright \& Sutton, 1990). Researchers confirm that ripening of ascospores occurs gradually and the dispersal of ascospores continues throughout the growing season period. Conidia develop only on senescent spots (De Wolf et al., 1998). During the period of rainfall and high air humidity, multiple cycles of conidial production and release occur, which leads to rapid development of tan spot in the following month (Ronis \& Semaškiene, 2011).

Septoria leaf blotch is the most important wheat disease in the majority of European countries, and grain yield losses can reach $65-75 \%$ when conditions are favourable for the disease development (Jørgensen et al., 2014). The symptoms are yellowish or chlorotic flecks and necrotic blotches containing a varying density of small black pycnidia (Kema et al., 1996).

$Z$. tritici is a polycyclic pathogen reproducing both sexually and asexually, resulting in infections initiated by two types of spores (ascospores and conidia). The research results show that the incidence and severity of Septoria leaf blotch depends on meteorological conditions (Kuzdralinski et al., 2015; Bankina et al., 2018.)

Under field conditions, the latent stage of $Z$. tritici persists for approximately 14 days; in colder weather, this time protracts up to 28 days (Fones \& Gurr, 2015; Suffert \& Thompson, 2018), but in other literature sources - up to 36 days (Steinberg, 2015). Early epidemics were preceded by almost constant average daily temperatures of $13.2 \pm 0.8^{\circ} \mathrm{C}$ between 181 and 210 days after sowing. Late epidemics were preceded by an approximately linear increase in temperature from $8.7 \pm 0.9$ to $12.1 \pm 0.9^{\circ} \mathrm{C}$ (Beyer et al., 2012). The mean latent period for seedlings was significantly shorter than that for adult plants (Suffert, \& Thompson, 2018).

The causal agent of yellow rust Puccini striiformis is an obligate parasite. The pathogen overwinters on green plants. Symptoms appear about one week after infection, and sporulation starts about two weeks later (Khanfri, Boulif, \& Lahlali, 2018). Initial symptoms are tiny, yellow to orange-coloured rust pustules which contain urediniospores. Spots develop into long and narrow stripes on leaf sheaths, glumes, and awns (Chen, 2005). Stripes of uredia or necrosis are formed generally after stem elongation. Spore germination, infection and survival are directly affected by moisture. Favourable conditionis light rain, but abundant moisture can also negatively affect spore viability (Chen, 2005; Khanfri, Boulif, \& Lahlali, 2018). The surveys confirm that yellow rust occurred periodically (Bankina, Jakobija, \& Bimšteine, 2011; Matzen et al., 2019). Warmer winters can promote earlier yellow rust infection and spread. Researchers prognosticate that the severity of the epidemics will increase throughout all wheat growing regions. Growing resistant varieties is the major component of integrated control of yellow rust (El Jarroudi et al., 2014; Ali et al., 2017; Khanfri, Boulif, \& Lahlali, 2018).

Powdery mildew (caused by Blumeria graminis) is common but its incidence and severity are low (Olesen et al., 2003; Bankina, Jakobija, \& Bimšteine, 2011; Bankina et al., 2018). Powdery mildew infects mainly leaves, but it can also infect leaf sheath, stem, and ear. The infection of powdery mildew was serious in a sowing where plant density was high and ventilation was poor (Olesen et al., 2003; Gao, Niu, $\& \mathrm{Li}, 2018)$. The results of the studies show that the yield reduction depends on the time and severity of the onset of the disease. When the infection occurs at the seedling stage, the growth and development of wheat is impaired and the plants are likely to die. When the infection occurs at the tillering stage, powdery mildew can delay the formation of wheat roots and decrease the formation of tillers. The occurrence of powdery mildew at heading and blooming stages may result in a reduction of the number of grains per ear, grain fullness and grain weight (Gao, Niu, \& Li, 2018).

The impact of cultural methods on diseases

Many investigations have been carried out to clarify the importance of cultural methods on disease severity.

Most studied cultural methods are crop rotation and tillage; however, the results are contradictory. They show that crop rotation and an efficient residue management are effective tools for reducing tan spot in winter wheat (Cotuna et al., 2015); however, in a study conducted in Latvia, the previous crop did not significantly affect the level of Septoria leaf blotch (Bankina et al., 2018). In a repeated wheat sowing, tan spot infection started earlier (Bankina et al., 2018) 
and achieved a higher severity level (Kuzdralinski et al., 2015; Fernandez et al., 2016; Bankina et al., 2018). Short crop rotations, where oilseed rape and wheat were included, provided a sufficient decrease in tan spot severity only in the fields under traditional soil tillage with ploughing at the depth of $22-24 \mathrm{~cm}$ (Bankina et al., 2018). A field experiment in Canada showed that a minimum of two years between wheat crops is necessary to prevent Septoria leaf blotch, but one year between wheat crops may be sufficient to control tan spot (Duczek et al., 1999).

The results of many experiments demonstrate that the severity of tan spot under reduced tillage was greater than that under traditional tillage (Bankina et al., 2014, 2018; Fernandez et al., 2016). The results from Denmark verified that non-inversion tillage increased the severity of tan spot and Fusarium head blight. The assessments of the severity of tan spot carried out at BBCH GS 31 (first node detectable) showed that the level of tan spot in plots with reduced tillage was $4-10$ times higher than in ploughed plots. Non-inversion tillage reduced the severity of powdery mildew and Septoria leaf blotch (Jørgensen \& Olesen, 2007), but a long-term experiment in Latvia demonstrated that the development of Septoria leaf blotch mainly depends on meteorological conditions but agronomic practices are less important (Bankina et al., 2018).The results of field trials in Romania showed that under both minimum and no-tillage systems with residues, the tan spot epidemic occurs earlier than under conventional tillage, and higher levels of disease severity are recorded during grain filling stage (Cotuna et al., 2015).

The results of the studies confirm that the use of disease resistant varieties is the most economical, safe and effective way to prevent and control wheat leaf diseases (Gao, Niu, \& Li, 2018). In Denmark, the differences in yields between the susceptible varieties and the moderately resistant varieties to tan spot in untreated plots were $0.5-1.0 \mathrm{t} \mathrm{ha}^{-1}$ depending on season (Jørgensen \& Olesen, 2007). The selection of varieties resistant to Septoria leaf blotch and tan spot in repeated wheat sowings increased the yields on average by $700 \mathrm{~kg} \mathrm{ha}^{-1}$ (Mazzili et al., 2016). An experiment in the Czech Republic showed that the impact of variety resistance to Septoria leaf blotch on the reduction of grain yield losses was significant. Compared to the $34.7 \%$ reduction in grain weight per spike in the susceptible variety 'Bakfis', the resistant variety 'Arina' showed only a $17.3 \%$ reduction (Šip, Chrpova, \& Palicova, 2015).

Decision-support systems

The results of researches show that the development of wheat diseases depends on many factors and decision-support systems are essential for optimizing and minimizing the use of fungicides.
The development of decision-support systems for the control of diseases in cereals started in the late 1980s. Now, many European countries have a number of forecasting and warning systems for optimizing and minimizing the use of fungicides. For example, the Danish decision-support system 'PCPlant Protection' was introduced in 1993, but in 2002 , it was reintroduced as a web-based decision-support system and is now called 'Crop Protection Online' (Hagelskjæ \& Jørgensen, 2003).

An accurate identification of pathogens and the determination of pathogen-specific control thresholds are key elements of the integrated pest management programs and decision-support systems. The threshold defines the optimal time for applying fungicide, when infection material transfers from the primary source of infection to the upper, yield-essential leaves (Verreet, Klink, \& Hoffmann, 2000). Thresholds for the major diseases of wheat in different decision support systems vary significantly. For example, the threshold for tan spot in France and the Netherlands are the first symptoms on upper leaves. In Germany, the use of pesticides is recommended only in cases with minimal tillage and the previous plant being wheat, if $10 \%$ of plants are attacked on the upper three leaves between BBCH GS 35 and BBCH GS 65. In Denmark and Sweden, tan spot is considered devastating only in fields with minimal tillage and the pre-crop of wheat. The threshold for susceptible cultivars is $75 \%$ of plants attacked at BBCH GS $31-32$ and $25 \%$ of plants attacked at BBCH GS $33-60$. In the United Kingdom and Hungary, there is no threshold for tan spot (Jørgensen et al., 2014). The researches in Latvia reveal that recommendations should be based on the disease incidence on the third or second leaf of wheat (Bankina et al., 2014).

Meteorological conditions are important factors in the development of fungal diseases in winter wheat (Bankina et al., 2018; Fernandez et al., 2016; Castro et $a l ., 2018)$ and are the main inputs of decision-support systems (El Jaroudi et al., 2017). The mostly used parameters are air temperature, relative air humidity, and precipitation (Greiner et al., 2019). For example, in the decision-support system 'PROCULTURE', certain meteorological conditions must be observed for the infection to occur: during 2-hour rainfall, in the first hour, rainfall must be at least $0,1 \mathrm{~mm}$ to allow for the swelling of pycnidia and be followed by at least $0,5 \mathrm{~mm}$ during the second hour to aid in spore release and splashing. In addition to the rainfall, the relative humidity must be above $60 \%$ within 16 hours after the rain event and the temperature must remain $4{ }^{\circ} \mathrm{C}$ for 24 hours (El Jarroudi, 2009, 2017).

In the Danish decision support system 'PC-Plant Protection', the forecasting of disease depends on pathogen type. The system includes models for 
powdery mildew, rusts, Septoria leaf blotch, net blotch, and eyespot. The models are based on control thresholds, but for splash-borne pathogens such as M. graminicola, the degree of infection is replaced by the number of days with precipitations more than $1 \mathrm{~mm}$ during the past days or weeks. The models assume a 10-day period of protection of splash-borne pathogens and 14 days for B. graminis and Puccinia spp. (Hagelskjæ \& Jørgensen, 2003).

There were many investigations on the effectivity of decision-support systems, and the results obtained are contradictory. For example, the evaluation of the cost effectiveness of the decision-support system 'PROCULTURE' shows that the decision support system-based recommendation resulted in significant grain yield increases compared to the control in years with a high disease pressure. The yield increase was $4-42 \%$, depending on the site and year. The financial gain in treated plots compared to the control ranged between 3 and $16 \%$ at the study sites. In seasons when dry weather conditions precluded the development of epidemic, the decision-support system recommended no fungicide spray, reducing the use of fungicides and thus saving the cost of the product (El Jaroudi et al., 2015). Studies have shown that there is no significant distinction among grain quality indicators (thousand grain weight, specific weight and grain starch content) for the three different methods using either one or two applications of treatment, or treatments according to the decision-support system (Matzen et al., 2019). The results of research in Latvia in 2008 - 2012 confirm that considerably higher yields were obtained in treatments with fungicide application, but differences between control strategies were not significant (Bankina et al., 2018).

Decision-support systems have been developed in countries with a milder climate and a longer vegetation period than Latvia, and systems need to be adapted to Latvian conditions.

\section{Fungicides}

Fungicides are intensively used as a part of disease management. Azoles, strobilurin, and carboxamides are the main groups of fungicides for disease control in winter wheat. There are many studies about the effectiveness of fungicide groups, however obtained results differ.

The main aim of using fungicides is to maintain the green leaf area (Gaurilčikienè, Butkutè, \& Mankevičienè, 2010; Bankina et al., 2014; Matzen et al., 2019). For example, the results of researches in Argentina confirm that fungicide treatments increased green leaf area duration (GLAD) on average by $16 \%$ compared to the control treatment. In the wettest years, GLAD means were even $51.7 \%$ higher than in the driest years when Septoria leaf blotch was the prevalent disease (Castro et al., 2018). As a result, fungicide application significantly decreased the AUDPC values of Septoria leaf blotch and tan spot (Castro et al., 2018; Fleitas et al., 2018). Unfortunately, researchers found no significant differences between fungicide variants (tested variants for Septoria leaf blotch: TS (triazole + strobilurin), T (triazole), and UT (untreated); for tan spot: TSC (triazole+strobilurin+carboxamide), TS (triazole + strobilurin), and UT (untreated)) (Castro et al., 2018). In another field trial in Argentina, the fungicide group significantly influenced the duration of the leaf green area; however, significant differences were found among fungicide groups. Leaf green area duration of wheat (on average 130 days) was significantly more extended if the mixture of triazole+strobilurin+carboxamide was used. The use of the mixture of triazole and strobilurin provided leaf green area duration on average for 114 days, but in the untreated variant - for only 78.8 days (Fleitas et al., 2018). The researches in Latvia proved that the largest leaf green area was observed in variants where fungicides with active ingredients containing strobilurin were used. The efficacy of two fungicide treatments was not increased if compared to a single application (Bankina et al., 2014).

The research data show that fungicides increased grain yields significantly (Bankina et al., 2014; Castro et al., 2018; Matzen et al., 2019). In Sweden, data from 350 field experiments performed in 1996-2011 showed that the mean yield increase in fungicidetreated plots was $10 \%$ if compared to untreated plots, and ranged between 0.39 and $3.39 \mathrm{t} \mathrm{ha}^{-1}$ depending on year (Djurle, Twengström, \& Andersson, 2018). In Argentina, the grain yield increase was 30.5\% after fungicide application (Castro et al., 2018). Wegulo, Breatnach and Baenziger (2009) obtained a yield increase that varied from $27 \%$ to even $42 \%$ after fungicide application. Long-term investigations have demonstrated that the change of fungicide group (from azole to strobilurin) provided a higher yield increase $\left(970 \mathrm{~kg} \mathrm{ha}^{-1}\right)$ compared to earlier years (only $660 \mathrm{~kg} \mathrm{ha}^{-1}$ ). The increasing of thousand grain weight by $1 \mathrm{~g}$ due to fungicide treatment just before/ during heading increased the yield by approximately $2000 \mathrm{~kg} \mathrm{ha}^{-1}$ (Wiik, 2009). In other study, Ronis et al. (2014) obtained an increase in thousand grain weight from 0.70 to $5.88 \mathrm{~g}$ compared to the grain weight in untreated plots. The results of experiments show that the increase in grain yield depended on fungicide group and even on active ingredients of a fungicide. For example, in Argentina, the grain yield increase per day under fungicide treatment containing triazole+strobilurin+carboxamide (fluxapyroxad) was $34.2 \mathrm{~kg} \mathrm{ha}^{-1}$ day $^{-1}$, under fungicide treatment containing triazole+strobilurin- from 18.1 to $34.2 \mathrm{~kg} \mathrm{ha}^{-1}$ day $^{-1}$, and without fungicide treatment - only $10.1 \mathrm{~kg} \mathrm{ha}^{-1}$ day $^{-1}$. In Lithuania, a single epoxyconazole application 
increased the grain yield from 0.31 to $1.77 \mathrm{t} \mathrm{ha}^{-1}$, but prothioconazole application increased the grain yield from 0.22 to $0.94 \mathrm{t} \mathrm{ha}^{-1}$ (Ronis et al., 2014).

Fungicide significantly influences the grain chemical content. It has been reported that fungicide considerably increased grain starch content compared to untreated variant (Matzen et al., 2019). The results about the influence of fungicide treatments on grain protein content are contradictory. An experiment in Lithuania confirmed that the application of fungicides (both strobilurins and triazoles) at the end of bootingheading stages (GS 47 - 55) essentially increased the yields of grain protein and gluten. The highest average protein yield was obtained when the fungicide used contained both strobilurin and epoxyconazole (Gaurilčikienè, Butkute, \& Mankevičienè, 2010).The researchers in Argentina found that application of 0 $70 \mathrm{~kg} \mathrm{~N} \mathrm{ha}^{-1}$ decreased the grain protein content when fungicides were used, particularly under the mixture of triazole, strobilurin and carboxamide (Castro et al., 2018). Similar results were obtained in Denmark. The control of Septoria leaf blotch, yellow rust, and powdery mildew reduced the grain protein content significantly (Matzen et al., 2019).

While fungicides are regularly used to protect the flag leaf, the decision to use the fungicide generally depends on local environmental conditions and the timing of disease detection. In general, one to three applications are used each season, depending on the pressure of the disease, susceptibility of variety and yield potential. For example, the protection of wheat in Grand-Duchy of Luxembourg largely depends on early fungicide use before severe symptoms appear that can reduce grain yields. Beyer et al. (2012) confirm that an early $Z$. tritici epidemic (about 245 days after sowing) is more devastating than late epidemics (epidemics around 270 days after sowing) and requires an accurate prognosis for early epidemics. The first spray is used during the period of stem elongation and is aimed to control early-season diseases, including powdery mildew and eyespot. The second fungicide application is usually intended to protect the flag leaf from the Septoria leaf blotch. The third application is used at early flowering stage to protect wheat against Fusarium head blight infection (caused by Fusariumgraminearum Schwabe) (El Jarroudi et al., 2017). Jørgensen and Olsen (2007) recommended a three-spray fungicide method in conditions favourable to the development of tan spot, but in most cases, the strategy of one or two applications provided sufficient control. The best controls were observed by the usage of products containing strobilurin (pyraclostrobin, picoxystrobin, and azoxystrobin) together with products containing propiconazole. The profitability of fungicide use depends on the level of yield, the increase in actual yields from the treatment, treatment expenses and the sales prices of wheat. Wegulo, Breathnach and Baenziger (2009) found that the use of the fungicide INBBCH GS 31 and later $\mathrm{BBCH}$ GS 39 may reduce the intensity of the disease and increase the yield by more than one fungicide, either BBCH GS 31 or BBCH GS 39. However, applications at BBCH GS 31 and BBCH GS 39 might not be costefficient, depending on the disease level, the costs of fungicide and its application, and the price of wheat. Researchers emphasise that the use of foliar fungicides earlier than BBCH GS 39 can be justified and can only be useful if environmental conditions contribute to the development of a severe disease at the beginning of the growing season. A growing amount of precipitation (rain) and days with rainfall coincided with profitable fungicide treatments more frequently than in drier conditions (Djurle, Twengström, \& Andersson, 2018). Studies carried out in Sweden have shown that fungicide use was profitable in 188 cases and was not profitable in 162 cases when a wheat price of 1 SEK per $\mathrm{kg}$ was used. The rise in the price of wheat to 1.50 SEK per kg resulted in 260 treatments that made a profit and 90 treatments that caused economic losses (Djurle, Twengström, \& Andersson, 2018).

The results of many studies show that the effectiveness of fungicides depended on different factors, such as pressure of diseases, meteorological conditions, region and economic situation, therefore the universal systems are not effective, they must be adapted to the local conditions.

\section{Conclusions}

1. The important part of integrated control of diseases is cultural methods such as crop rotation, tillage and the use of disease resistant varieties.

2. The development of wheat diseases depends on many factors and warning and forecasting systems are essential for optimizing and minimizing the use of fungicides. Many European countries have a number of decision-support systems, based on control thresholds and meteorological observations. These systems have been developed in countries with a milder climate and a longer vegetation period than Latvia, so they need to be adapted to the Latvian conditions.

3. The main fungicides for disease control in winter wheat are azoles, strobilurin, and carboxamides. In general, one to three applications are used each season, depending on the pressure of the disease, susceptibility of variety and yield potential. The results of many studies show that the effectiveness of fungicides depend on different factors, such as pressure of diseases, meteorological conditions, region and economic situation, therefore the universal systems are not effective, they must be adapted to local condition. 


\section{Acknowledgements}

The research was supported by the EIO-AGRI Operational Group project 'Decision making system-
Development of a decision making support system for the reduction of winter wheat leaf and hoof diseases'

\section{References}

1. Ali, S., Rodrigues-Algaba, J., Thach, T., Sórensen, C., Hansen, J.G, Lassen, P., Nazari, K., Hodson, D.P., Justesen, A.F., \& Hovmøller, M.S. (2017). Yellow rust epidemics worldwide were caused by pathogen races from divergent genetic lineages. Frontiers in Plant Scienc. 8, article 1057. DOI: 10.3389/fpls.2017.01057.

2. Bankina, B., \& Priekule, I. (2011). A review of tan spot research in the Baltic countries: occurrence, biology and possibilities of control. Zemdirbyste=Agriculture. 98(1), 3-10.

3. Bankina, B., Bimšteine, G., Arhipova, I., Kaṇeps, J., \& Stanka, T. (2018). Importance of agronomic practice on the control of wheat leaf diseases. Agriculture, 8, 56. DOI: 10.3390/agriculture8040056.

4. Bankina, B., Gaile, Z., Balodis, O., Bimšteine, G., Katamadze, M., Kreita, Dz., Paura, L., \& Priekule, I. (2014). Harmful winter wheat diseases and possibilities for integrated control in Latvia. Acta Agriculturae Scandinavica, Section B - Soil \& Plant. 64(7), 615-622. DOI: 10.1080/09064710.2014.949296.

5. Bankina, B., Jakobija, I., \& Bimšteine, G. (2011). Peculiarities of wheat leaf disease distribution in Latvia. Acta Biologica Universitatis Daugavpiliensis. 11(1), 88-95.

6. Barzman, M., Bàrberi, P., Birch, A.N.E., Boonekamp, P., Dachbrodt-Saaydeh, S., Graf, B., Hommel, B., Jensen, J.E., Kiss, J., Kudsk, P., Lamichhane, J.R., Messéan, A., Moonen, A.C., Ratnadass, A., Ricci, P., Sarah, J.L., \& Sattin, M. (2015). Eight principles of integrated pest management. Agronomy of Sustainable Development. 35(4), 1199-1215. DOI: 10.1007/s13593-015-0327-9.

7. Beyer, M., El Jaroudi, M., Junk, J., Pogoda, F., Dubos, T., Görgen, K., \& Hoffmann, L. (2012). Spring air temperature accounts for the bimodal temporal distribution of Septoria tritici epidemics in the winter wheat stands of Luxembourg. Crop Protection. 42, 250-255. DOI: 10.1016/j.cropro.2012.07.015.

8. Castro, A.C., Fleitas, M.C., Schierenbeck, M., Gerard, G.S., \& Simón, M.R. (2018). Evaluation of different fungicides and nitrogen rates on grain yield and bread-making quality in wheat affected by Septoria tritici blotch and yellow spot. Journal of Cereal Science. 83, 49-57. DOI: 10.1016/j.jcs.2018.07.014.

9. Chen, X.M. (2005). Epidemiology and control of stripe rust (Puccinia striiformis f. sp. tritici) on wheat. Canadian Journal of Plant Pathology. 27(3), 314-337. DOI: 10.1080/07060660660509507230.

10. Cotuna, O., Paraschivu, M., Paraschivu, A.M., \& Sarateanu, V. (2015). The influence of tillage, crop rotation and residue management on tan spot (Drechslera tritici repentis. Died. Shoemaker) in winter wheat. Research Journal of Agricultural Science. 47(2), 13-21.

11. Centrālā Statistikas pārvalde (CSB - Central Statistical Bureau). (2019). Lauksaimniecības kultūru sējumu platība (tūkst. ha) (The crop sown area (thous. ha)). Retrieved March 14, 2019, from http://data1.csb.gov. lv/pxweb/lv/lauks/lauks_03Augk_ikgad/LAG020.px/?rxid=a39c3f49-e95e-43e7-b4f0-dce111b48ba1.

12. De Wolf, E.D., Effertz, R.J., Ali, S., \& Francl, L.J. (1998). Vistas of tan spot research. Canadian Journal of Plant Pathology. 20(4), 349-444.

13. Djurle, A., Twengström, E., \&Andersson, B. (2018). Fungicide treatments in winter wheat: the probability of profitability. Crop Protection. 106, 182-189. DOI: 10.1016/j.cropro.2017.12.018.

14. Duczek, L.J., Sutherland, K.A., Reed, S.L., Bailey, K.L., \& Lafond, G.P. (1999). Survival of leaf spot pathogens on crop residues of wheat and barley in Saskatchewan. Canadian Journal of Plant Pathology. 21(2), 165-173. DOI: 10.1080/070606699095018.

15. El Jarroudi, M., Delfosse, P., Maraite, H., Hoffmann, L., \& Tychon, B. (2009). Assessing the accuracy of simulation model for Septoria leaf blotch disease progress on winter wheat. Plant Diseases. 93, 983-992. DOI: 10.1094/PDIS-93-10-0983.

16. El Jarroudi, M., Kouadio, L., Delfosse, P., \& Tychob, B. (2014). Brown rust disease control in winter wheat: I. Exploring an approach for disease progression based on night weather conditions. Environmental Science and Pollution Research. 21, 4797-4808. DOI: 10.1007/s11356-013-2463-6.

17. El Jarroudi, M., Kouadio, L., Beyer, M., Junk, J., Hoffmann, L., Tuchona, B., Maraite, H., Bocke, C.H., \& Delfosse, P. (2015). Economics of a decision-support system for managing the main fungal diseases of winter wheat in the Grand-Duchy of Luxembourg. Field Crops Research. 172, 32-41. DOI: 10.1016/j. fcr.2014.11.012.

18. El Jarroudi, M., Kouadoi, L., El Jarroudi, M., Junk, J., Bock, C., Diouf, A.A., \& Delfosse, P. (2017). Improving fungal disease forecasts in winter wheat: a critical role of intraday variations of meteorological conditions in the development of Septoria leaf blotch. Field Crop Research. 213, 12-20. DOI: 10.1016./j. fcr.2017.07.012. 
19. Fernandez, M.R., Stevenson, C.F., Hodge, K., Dokken-Bouchard, F., Pearse, P.G., Waelchli, F., Brown, A., \& Peluola, C. (2016). Assessing effects of climatic change, region and agronomic practices on leaf spotting of bread and durum wheat in the Western Canadian prairies, from 2001 to 2012. Agronomy Journal. 108(3), 1180-1195. DOI: 10.2134/agronj2015.0451.

20. Fleitas, M.C., Schierenbeck, M., Gerarda, G.S., Dietza, J.I., Golika, S.I., \& Simón, M.R. (2018). Bread making quality and yield response to the green leaf area duration caused by fluxapyroxad under three nitrogen rates in wheat affected with tan spot. Crop Protection. 106, 201-209. DOI: 10.1016/j.cropro.2018.01.004.

21. Fones, H., \& Gurr, S. (2015). The impact of Septoria tritici blotch disease on wheat: An EU perspective. Fungal Genetics and Biology. 79, 3-4. DOI:10.1016/j.fgb.2015.04.004.

22. Hagelskjæ, L., \& Jørgensen, L.N. (2013). A web-based decision support system for integrated management of cereal pests. EPPO Bulletin. 33(3), 467-471. DOI: 10.1111/j.1365-2338.2003.00681.x.

23. Gao, H., Nui, J., \& Li, S. (2018). Impacts of wheat powdery mildew on grain yield \& quality and its prevention and control methods. American Journal of Agriculture and Forestry. 6(5), 141-147. DOI: 10.11648/j.ajaf.20180605.14.

24. Gaurilčikienè, I., Butkutė, B., \& Mankevičienė, A. (2010). A multi-aspect comparative investigation on the use of strobilurin and triazole-based fungicides for winter wheat disease control. In Odile Carisse (Ed.), Fungicides (pp. 69-94). InTech, ISBN: 978-953-307-266-1.

25. Greiner, S.D., Racca, P., Jung, J., \& von Tiedemann, A. (2019). Determining and modelling the effective period of fungicides against Septoria leaf blotch in winter wheat. Crop Protection. 117, 45-51. DOI: 10.1016/j.cropro.2018.11.004.

26. Jørgensen, L.N., \& Olesen, L.V. (2007). Control of tan spot (Drechlera tritici-repentis) using cultivar resistance, tillage methods and fungicides. Crop Protection. 26, 1606-1616. DOI: 10.1016/j. cropro.2007.01.009.

27. Jørgensen, L.N., Hovmøller, M.S., Hansen, J.G., Lassen, P., Clark, B., Bayles, R., Rodemann, B., Flath, K., Jahn, M., Goral, T., Czembor, J.J., Cheyron, P., Maumene, C., De Pope, C., Ban, R., Nielsen, G.C., \& Berg, G. (2014). IPM strategies and their dilemmas including an introduction to www.eurowheat.org. Journal of Integrative Agriculture. 13(2), 265-281. DOI: 10.1016/S2095-3119(13)60646-2.

28. Kema, G.H.J., Yu, D., Rijkenberg, F.H.J., Shaw, M.W., \& Baayen, R.P. (1996). Histology of the pathogenesis of Mycosphaerella graminicola. Phytophatalogy. 86(7), 777-786. DOI: 10.1094/Phyto-86-777.

29. Khanfri, S., Boulif, M., \& Lahlali, R. (2018). Yellow rust (Puccinia striiformis): a serious threat to wheat production worldwide. Not. Sci. Biol. 10(3), 410-423. DOI: 10.15835/nsb10310287.

30. Kuzdralinski, A., Szczerba, H., Tofil, K., Filipiak, A., Garbarczyk, E., Dziadko, P., Muszynska, M., \& Solarska, E. (2015). Early PCR detection of the Mycosphaerella graminicola in the leaves of winter wheat in Poland. Romanian Agricultural Research. 32, 273-277.

31. Matzen, N., Jørgensen, J.R., Holst, N., \& Jørgensen, L.N. (2019). Grain quality in wheat - impact of disease management. European Journal of Agronomy. 103, 152-164.

32. Mazzili, S.R., Ernst, O.R., Pereira de Mello, V., \& Pérez, C.A. (2016). Yield losses on wheat crops associated to the previous winter crop: Impact of agronomic practices based on on-farm analysis. European Journal of Agronomy. 75, 99-104. DOI: 10.1016/j.eja.2016.01.007.

33. Olesen, J.E., Jørgensen, L.N., Petersen, J., \& Mortensen, J.V. (2003). Effects of rate and timing of nitrogen fertilizer on disease control by fungicides in winter wheat. 1. Grain yield and foliar disease control. Journal of Agricultural Science. 140, 1-13. DOI: 10.1017/S0021859602002885.

34. Ronis, A., \& Semaškiene, R. (2011). Relationship of AUDPC values of tan spot and Stagonospora glume blotch with grain infection in winter and spring wheat. Zemdirbyste=Agriculture. 98(1), 11-18.

35. Ronis, A., Jørgensen, L.N., Semaškienė, R., Gaurilčikienė, I., \& Ramanauskienė, J. (2014). Sensitivity of Mycosphaerella graminicola isolates to demethylation-inhibiting (DMI) fungicides. Zemdirbyste=Agriculture 101(2), 177-184. DOI: 10.13080/z-a.2014.101.023.

36. Steinberg, G. (2015). Cell biology of Zymoseptoria tritici: Pathogen cell organization and wheat infection. Fungal Genetics and Biology. 79, 17-23. DOI: 10.1016/j.fgb.2015.04.002.

37. Suffert, F., \& Thompson, R.N. (2018). Some reasons why the latent period should not always be considered constant over the course of a plant disease epidemic. Plant Pathology. 67, 1831-1840. DOI: 10.1111/ ppa.12894.

38. Šip, V., Chrpova, J., \& Palicova, J. (2015). Response of selected winter wheat cultivars to inoculation with different Mycosphaerella graminicola isolates. Genetic Plant Breed. (3)51, 86-95. DOI: 10.17221/44/2015-CjGPB.

39. Verreet, J.A., Klink, H., \& Hoffmann, G.M. (2000). Regional monitoring for disease prediction and optimization of plant protection measures: the IPM wheat model. Plant Disease. 84, 816-826. 
40. Wegulo, S.T., Breathnach, J.A., \& Baenziger, P.S. (2009). Effect of growth stage on the relationship between tan spot and spot blotch severity and yield in winter wheat. Crop Protection. 28, 696-702. DOI: 10.1016/j.cropro.2009.04.003.

41. Wiik, L. (209) Yield and disease control in winter wheat in Southern Sweden during 1977-2005. Crop Protection. 28, 82-89. DOI: 10.1016/j.cropro.2008.09.002.

42. Wright, K.H., \& Sutton, J.C. (1990). Inoculum of Pyrenophora tritici-repentis in relation to epidemics of tan spot of winter wheat in Ontario. Canadian Journal Plant Pathology. 12, 149-157. DOI: 10.1080/07060669009501018. 